Georgia State University

ScholarWorks @ Georgia State University

\title{
The Impact of Veterans' Preference on the Composition and Quality of the Federal Civil Service
}

\author{
Gregory B. Lewis \\ Georgia State University, glewis@gsu.edu
}

Follow this and additional works at: https://scholarworks.gsu.edu/pmap_facpubs

Part of the Public Affairs, Public Policy and Public Administration Commons

\section{Recommended Citation}

Lewis, Gregory B., "The Impact of Veterans' Preference on the Composition and Quality of the Federal Civil Service" (2013). PMAP Publications. 9.

https://scholarworks.gsu.edu/pmap_facpubs/9

This Article is brought to you for free and open access by the Department of Public Management and Policy at ScholarWorks@ Georgia State University. It has been accepted for inclusion in PMAP Publications by an authorized administrator of ScholarWorks @ Georgia State University. For more information, please contact scholarworks@gsu.edu. 


\title{
The Impact of Veterans' Preference
}

\section{on the Composition and Quality of the Federal Civil Service}

\begin{abstract}
U.S. governments have long explicitly preferred military veterans in hiring, as a way of honoring them for their service and sacrifices. I examine the effect of this preference on the diversity and quality of the public service. Census data for 1990, 2000, and 2006-9 show that veterans are at least three times as likely to hold federal jobs as, but only $10 \%$ more likely to hold state and federal government jobs than, comparable individuals without military service. Preferential treatment of veterans has dramatically increased the percentage of federal employees who are men and has probably decreased the percentages who are Asians, gay men, and immigrants, but effects on the composition of state and local governments is small. Federal personnel data for the past decade show that veteran new hires are older and less educated than nonveteran new hires, and that they do not advance as far in the first fifteen years of their careers as nonveterans hired into the same grades at the same time, suggesting that veterans' preference may be lowering the performance of the federal service.
\end{abstract}




\section{The Impact of Veterans' Preference on the Federal Civil Service}

Veterans' preference ... severely limits job opportunities for people who are not

veterans. It particularly diminishes the employment chances of women (GAO 1977, 1).

Agencies prefer using noncompetitive hiring mechanisms where they do not have to

apply veterans' preference points and the Rule of Three (GAO 1995, 5-6)

Commonly recognized goals of the federal personnel system include increasing the quality, equity, diversity, representativeness, responsiveness, and managerial effectiveness of the civil service. One-quarter of federal employees, however, are hired through a mechanism designed to fulfill a different goal: to recognize and reward veterans for their service to and sacrifices for the nation. Fulfilling this goal may require tradeoffs with other goals. By explicitly preferring a group that has traditionally been very disproportionately male, white, and heterosexual, veterans' preference creates obstacles to the diversity and may decrease the representativeness of the federal service. By creating red tape to protect veterans' rights, preference limits managerial discretion in hiring and may push managers toward alternative hiring mechanisms. By crediting military service in hiring, veterans' preference challenges merit principles and may lower the quality of the civil service.

Although veterans' preference has attracted occasional scholarly attention and several government reports, we still know strikingly little about (1) how much it impacts who gets federal jobs, (2) how much it alters the composition of the federal workforce, and (3) how it affects the qualifications and quality of federal employees. After briefly recounting the history of veterans' preference and reviewing the findings of a handful of federal and academic studies, this article provides a more systematic analysis of the effect of veterans' preference on the 
federal service. Using Census data for 1990, 2000, and 2006-9, it first shows that veterans are three to four times as likely to hold federal jobs as comparable nonveterans. It then examines how this affects women's, minorities', gay people's, and naturalized citizens' chances of federal employment, finding that veterans' preference has had a major impact on the gender composition of the federal service and smaller impacts on its representativeness in terms of race/ethnicity, sexual orientation, and country of origin. Using both Census data and federal personnel records for 1973 through 2009, it shows that veterans' preference probably leads to a less educated but more experienced civil service, with its overall impact on the quality of the federal service unclear.

\section{How much does veterans' preference affect who gets hired?}

The federal government has preferred disabled veterans in hiring at least since the Civil

War. Congress expanded preference to cover honorably discharged veterans and their widows after World War I, and it strengthened preference again as World War II was winding down (Lewis and Emmert 1984, 330). Although at times only those who had served in combat qualified for preference, preference was gradually widened to cover those who were honorably discharged after at least 180 days of service in wartime, including the Cold War and the Global War on Terror.

Under the Veterans' Preference Act of 1944, disabled veterans get 10 points and other veterans get 5 points added to their civil service examination scores (or to their numerical score, "when agencies use a numerical rating or ranking system" (FedsHireVets 2011)). Under the rule of three, which has only recently been overturned (Obama 2010, overturning 5 CFR 302.401(a)), federal hiring officials could only consider the top three candidates for a job, 
typically ranked by the U.S. Office of Personnel Management (OPM), its predecessor (the U.S. Civil Service Commission), or the agency's personnel/human resources office. For positions filled through a civil service examination, usually scored on a 100-point scale, disabled veterans with passing scores of 70 and above and other veterans with scores of 95 and above would rank higher than nonveterans with scores of 100. (Disabled veterans with passing scores "float" to the top of civil service registers, and other veterans are placed above nonveterans with the same final score (after adding the preference points).) At different times, hiring officials could not pass over a veteran to hire a lower-ranked nonveteran, except with a written explanation and OPM approval. The process is less formal in the absence of a civil service exam, especially since the abolition of the rule of three, but "when eligible candidates are referred without ranking, the agency shall note preference" (5 CFR 302.201) and veterans eligible for 10-point preference should be considered before those eligible for 5-point preference, who should be considered before those who do not qualify for preference (5 CFR 302.304(b)(5)(i)) .

How much do these five or ten points matter? Some researchers have considered veterans' preference merely a "limited preferential hiring program" (Berger and Hirsch 1983, 459), but others find a major impact. GAO (1977) indicated that $30 \%$ of the federal and only $15 \%$ of the nonfederal workforce were veterans. The veteran share of new hires has jumped after each expansion of veterans' preference (largely because expansions occur at the ends of wars). Veterans made up $14 \%$ of new hires in 1920 and $29 \%$ in 1921 . The veteran share of all federal employees rose from $14 \%$ in 1944 to $49 \%$ five years later, due both to the end of WWII and to passage of the Veterans Preference Act of 1944 (Lewis and Emmert 1984, 130). Blank (1985) finds that veterans are much more likely to work for government, especially the federal 
government, than nonveterans of the same sex, race, and experience and educational levels. Sanders $(2007,412)$ finds that veteran status raises the odds of a government job by about $40 \%$ for native-born citizens and nearly doubles them for immigrants, though Sanders does not examine federal employment separately from other public employment. Clearly, however, veterans are much more likely than nonveterans to be federal employees.

Military service, even in the absence of preference, might increase the likelihood of federal employment. Among their motivational bases for public service, Perry and Wise (1990, 370) list loyalty to duty and patriotism, two qualities frequently associated with veterans, as well as "commitment to a public program," due either to "personal identification" or "a genuine conviction about its social importance," which may lead veterans to prefer work with the Department of Defense (DOD). Indeed, $42 \%$ of DOD employees (and only $18 \%$ of other federal employees) are veterans (U.S. Office of Personnel Management 2011, Table 1A), suggesting that DOD may both need skills developed in the military and have a culture that values military service. However, $89 \%$ of veterans employed both by DOD and by domestic agencies receive preference (U.S. Office of Personnel Management 2011, Table 1), suggesting no particular attraction of veterans to DOD.

Preferential treatment will lead to over-representation of veterans, however, only if more people want federal jobs than can get them. State governments also offer veterans' preference - their programs vary in their details but appear roughly comparable to the federal program (Davis 1985) - but preference should have less impact on the composition of their workforces if state government jobs are less desirable than federal jobs. Public administration scholars generally argue that federal workers are underpaid (the President's Pay Agent (2011) 
indicates that the current pay disparity is at least 30\%). Labor economists, however, tend to find that federal workers earn substantially more than comparable workers in the private sector, though state and local government pay tends to be indistinguishable from or lower than private-sector pay (Smith 1975; Smith 1976; Krueger 1988; Moulton 1990). Although opportunities to serve the public and job security also attract people to government jobs even in the absence of pay advantages, the clear evidence of higher pay in the federal than state sector suggests that veterans' preference will disproportionately attract veterans to the federal service.

\section{Who benefits?}

Weighting military service in hiring decisions is likely to benefit male, white, heterosexual, native-born citizens over others. In pushing to weaken veterans' preference in the Civil Service Reform Act of 1978, U.S. Civil Service Commission Chairman Alan Campbell argued that "the present limitations favoring preferential hiring from a labor pool which is $98 \%$ male and $92 \%$ nonminority places an inordinate burden on Federal agencies trying to implement affirmative action" (quoted in Lewis and Emmert 1984, 329). Women could not make up more than $2 \%$ of the armed forces until 1967 (Elliott 1986), and the U.S. General Accounting Office (GAO 1977) reported that large numbers of highly qualified women could not be considered for federal jobs because, even with perfect scores on civil service examinations, they ranked lower than less educated and experienced veterans. Women now make up $14 \%$ of the U.S. military, but men still outnumber women by 6-to-1 (Clemmitt 2009). Several studies have found a negative impact of veterans' preference on women in the federal service (Keeton 
1994; Mani 1999; Emmert and Lewis 1982) and in state governments (see several studies in Hale and Kelly 1989).

The impact on minorities has attracted less attention, though the military clearly limited opportunities for African Americans and Asians in WWII. The military has become much more diverse, of course. In 2000, $66 \%$ of active duty military were white, $20 \%$ were black, $8 \%$ were Hispanic, and $4 \%$ were Asian, but meaning that whites and blacks were over-represented and Latinos and Asians were under-represented, relative to their shares of the military-age population (Lutz 2008, 177). “Don't Ask, Don't Tell" ended on September 20, 2011, but the military long prohibited the service of homosexuals (Berube 1990; Shilts 1993) and only partially loosened the restriction in 1993 (Rimmerman 1996). Lewis and Pitts (2011) find that partnered gay men, but not partnered lesbians, are less likely than comparable heterosexually partnered Americans to hold federal jobs, consistent with gay/lesbian patterns of under/overrepresentation in the military (Gates 2004$)$. Sanders $(2007,407)$ reports that $6.1 \%$ of employed male immigrants were veterans, but rates of military service for native-born males are substantially higher. Naturalized citizens who immigrated as adults may be hurt in their prospects for federal employment, due to a smaller probability of qualifying for veterans' preference (Lewis, Liu, and Edwards 2011).

Further, as federal hiring been fairly limited since the 1980s, the composition of the military in the past - when it was more white, male, and heterosexual - matters more for the composition of the federal service. With federal hiring accelerating as Baby Boomers retire, the increasing diversity of the military will mean that a more representative group of Americans will 
benefit from veterans' preference, but the composition of the federal service will evolve much more slowly.

\section{Managerial discretion and the quality of federal employees}

Veterans' preference has repeatedly raised concerns about merit principles and managerial hiring discretion. While Congress was considering expansion of veterans' preference at the end of WWI, the U.S. Civil Service Commission responded, "The civil-service law is based upon the principle that every citizen should have equal opportunity to appointment in the public service and that in each case the most efficient should be appointed" (quoted in Emmert and Lewis 1982, 48). A survey of state employees and personnel specialists found much greater dissatisfaction with veterans' preference among the personnel specialists, presumably due to their greater commitment to the merit principle (Elliott 1986).

The U.S. Merit Systems Protection Board (MSPB 1994, xii) argued that "veterans preference and the 'rule of three' [are] widely viewed as an impediment to good hiring practices. In fact, a good portion of the evolution in hiring methods that has occurred may have been molded by agency reaction to the combined effects of these two requirements rather than by a desire to use the best selection tools available." GAO (1992) reported that agencies frequently sent back registers that were headed by veterans in hopes that other agencies would hire them (allowing the original agency to go deeper on the registers to reach nonveterans they liked better) and were increasingly hiring through the Outstanding Scholar program (OSP), which allowed them to hire college graduates in the top $10 \%$ of their class or 
with grade point averages above 3.5 and to ignore veterans' preference. $^{1}$ OSP proved very popular with hiring officials: OSP hires rose from $1 \%$ to $9 \%$ of new hires in entry-level professional and administrative positions between 1984 and 1992 (MSPB 1994), and Tsugawa (2011) finds that $30 \%$ to $40 \%$ of entry-level professionals were hired through OSP in the mid- to late-1990s. In 2006, however, MSPB ruled that OSP violated the rights of veterans, and OPM strongly advised agencies not to use OSP.

In 2000, President Clinton created the Federal Career Intern Program (FCIP) "to attract exceptional men and women to the Federal workforce who have diverse professional experiences, academic training, and competencies, and to prepare them for careers in analyzing and implementing public programs" (E.O. 13162). Agencies could hire into entrylevel professional and administrative positions without public notice or competition and, following private sector practice, recruit and hire on college campuses and at job fairs (MSPB 2008, 15). FCIP hiring exploded under President Bush: by 2007 , about $70 \%$ of entry-level professional and administrative new hires entered under that hiring authority (Tsugawa 2011). In 2008, however, a federal court ruled that the DOD had violated a veteran's rights when it filled two auditor positions through FCIP rather than posting them competitively and awarding veterans' preference (Rosenberg 2009). MSPB subsequently ruled that FCIP violated veterans' rights more generally (Losey 2010), and President Obama dismantled it (E.O. 13562, December 2010). He has recently proposed regulations for a new "Pathways for Students \& Recent Graduates to Federal Careers" program that explicitly applies veterans' preference.

\footnotetext{
${ }^{1}$ OPM had created OSP in response to the Luevano consent decree (Luévano v. Campbell, 93 F.R.D. 68 (D.D.C. 1981)), which found that the Professional and Administrative Careers Examination adversely impacted blacks' and Latinos' chances of obtaining federal jobs.
} 
Thus, veterans' preference probably decreases the employment of college graduates in the federal service, and hiring officials apparently believe the program forces them to hire less qualified applicants. Several studies of career patterns in the federal service have tested the hypothesis that veterans' preference leads to veterans earning more than comparably qualified nonveterans (Taylor 1979; Grandjean 1981; Johnson and Libecap 1989; Lewis and Emmert 1984; Lewis 1988). Surprisingly, veterans actually earn less, leading to speculation that "veterans' preference, applied at entry to the federal service, places individuals of lower ability into jobs for which they would otherwise not qualify, while subsequent promotions are affected more by ability than by the veterans' preference" (Taylor 1979, 473). Presenting the economic logic, Berger and Hirsch $(1983,459)$ argue that "veterans should realize an earnings premium over nonveterans with similar characteristics. Within a given job, however, a veteran may be less productive and earn less than a nonveteran if the job was acquired as a result of preferential treatment." If veterans' preference does lead to lower quality applicants being hired, the quality of the civil service is likely to be unnecessarily poor.

In sum, veterans' preference may have major impacts on the civil service. Veterans who qualify for preference should be dramatically more likely than comparable nonveterans to obtain federal jobs, but only somewhat more likely to hold state and local government jobs, which pay less. Veterans' preference probably has the most negative impact on the employment of women, but it may also disadvantage Latinos, Asians, naturalized citizens, and people with same-sex partners, at least in the federal government. It probably decreases educational levels in the federal service. Further, if veterans' preference leads to veterans 
being hired above more-qualified nonveterans, veterans may receive lower performance ratings and fewer promotions later in the career.

\section{Data and Methods}

I work with two types of data: Census data on the full-time labor force and a $1 \%$ sample of personnel records for full-time, white-collar federal employees. The $5 \%$ Public Use Microdata Samples (PUMS) from the 1990 and the 2000 Census and the combined 2006-2009 American Community Surveys (ACS) each provides information on military service, sector of employment, and a variety of demographic and work characteristics for over 3 million full-time (36+ hours per week), full-year (50+ weeks) employees. (I drop the self-employed and parttime workers.)

Trying to determine whether people qualified for veterans' preference proved problematic, however. Respondents check all the periods in which they served in the U.S. military, from a list of 8 to 11 periods that closely resemble the periods U.S. Office of Personnel Management (OPM) uses to determine preference-eligibility, ${ }^{2}$ but OPM (2011) reports that $90 \%$ of federally employed veterans receive preference, and only $70 \%$ of federally employed veterans in the ACS sample reported military service during the periods that qualified for preference. Thus, two-thirds of the veterans I initially coded as not qualifying for preference probably did qualify, and they were nearly as likely to hold federal jobs as veterans who

\footnotetext{
2 The ACS uses the following periods: November 1941 or earlier, World War II (December 1941 to December 1946), January 1947 to June 1950, Korean War (July 1950 to January 1955), February 1955 to February 1961, Vietnam era (August 1964 to April 1975), May 1975 to August 19890, September 1980 to July 1990, August 1990 to August 2001 (including Persian Gulf War), and September 2001 or later. To qualify for veterans' preference in the federal service, one must have 180 or more consecutive days of active duty service since September 11, 2001; or between August 2, 1990 and January 2, 1992; or between January 31, 1955 and October 15, 1976; or between April 28, 1952 and July 1, 1955; or in World War II or the Cold War (between December 7, 1941 and April 28, 1952). http://www.fedshirevets.gov/job/vetpref/index.aspx.
} 
appeared to qualify for preference. I chose to use a single dummy variable to identify those who had served in the military.

The Census asks whether each employed person works for a private, for-profit company, a private not-for-profit or charitable organization, a local government, a state government, or the federal government. I simplified these into three sectors: federal, state and local, and private (including both for-profit firms and nonprofit organizations). To test the effects of military service on the probability of public sector employment, I begin with simple comparisons of the percentages of veterans and nonveterans who held jobs in each sector in each period (1990, 2000, and 2006-9).

I then run multinomial logit models to test whether veteran-nonveteran differences in education, age, race/ethnicity, gender, relationship status (married, living with an unmarried partner of the same or opposite sex, or unpartnered), citizenship status, and English language proficiency can explain differences in sector of employment. Because the huge sample sizes require no simplifying assumptions about the effects of age and education on the probability of federal employment, I restrict the sample to employees between the ages of 21 and 65 and use 45 dummy variables for year of birth and eight dummy variables for level of education. I also use sets of dummy variables for race/ethnicity and gender, for relationship status (e.g., man with male partner), and for citizenship status and English proficiency. Most of these are shown in Table 2.

With the private sector as the base category, coefficients show how one-unit increases in the independent variables affect the log-odds of federal (or state-local) employment relative to private sector employment. To make this more understandable, I calculate everyone's 
probabilities of working in each sector twice, once as a veteran and once as a nonveteran (coding the veteran variable first as a 1 , then as a 0 ), then calculate the mean probabilities of each sector of employment for veterans and nonveterans. The differences between these mean probabilities are called the average partial effect (Wooldridge 2009, 582). Because probabilities are nonlinear functions of the independent variables, this method holds the other variables constant at the actual distribution of the variables for the sample as a whole.

Using a single veteran variable implicitly assumes that being a veteran has the same impact on the log-odds of being in each sector for everyone. To allow the effect of veteran status to vary with race, sex, age, educational level, age, and sexual orientation, I repeat the multinomial logit models, adding interaction terms between veteran status and each of the other variables in the model. I again estimate each person's probability of working in each sector twice, once as a veteran and once as a nonveteran, and calculate the mean probabilities.

To test whether veterans' preference disproportionately benefits men, whites, heterosexuals, and native-born citizens - I first compare the characteristics of veterans and nonveterans, beginning with Census data for the three periods. I then look at my second data source: a one percent sample of the Central Personnel Data File (CPDF), which OPM maintains as the federal government's personnel records. I focus on all white-collar federal employees in 2009 and on employees hired into white-collar jobs from 2000 through 2009. I focus on race/ethnicity and sex, as the CPDF includes no information on marital status, sexual orientation, or citizenship status.

The CPDF does not explicitly identify new hires, so I use employees who first appear in the CPDF in 2000 or later. (OPM draws the sample in April of each year, based on the final 
three digits of the social security number, so that employees in the sample one year appear in every year in which they are federal employees in March.) This method introduces some error, as one-quarter of these new hires (71\% of those with veterans' preference and $15 \%$ of those without) already have more than 1.2 years of federal service. The most likely explanation is military service (the CPDF has no direct measure of it, but it is included in federal service for retirement and other purposes ${ }^{3}$ ), but these employees may also have returned to federal service after being out since 1973, transferred in from a non-reporting federal agency (e.g., the USPS or the $\mathrm{CIA}$ ), or had their hire paperwork delayed in reaching the CPDF.

Next, to estimate what the composition of the federal service would have been in the absence of veterans' preference, I re-run the multinomial logit models, restricting the sample to nonveterans. I then calculate the probabilities of employment in each sector for everyone (both veterans and nonveterans) as if the patterns that currently apply for nonveterans held for everyone. I then calculate mean probabilities by race/ethnicity and gender, by relationship status, and by citizenship status. I multiply those probabilities times the number of people of that characteristic in the sample to calculate the expected number and percentage of federal employees who would have each characteristic. This approach assumes that, in the absence of veterans' preference, individual characteristics would affect sector of employment the same way that they currently do for nonveterans. I expect the representation of women, Asians, gay people, and naturalized citizens would increase.

Testing the possibility that veterans' preference leads to a less qualified federal work force is tricky. I begin by examining the educational levels and ages (as a proxy for work

\footnotetext{
${ }^{3}$ The "service computation date" (SCD) is typically the date on which employees entered military or federal civilian service. When employees take leaves of absence, OPM adjusts their SCDs.
} 
experience) of veterans and nonveterans, on the expectation that the veterans are more experienced but less educated. Labor economists have demonstrated, however, that both education and experience increase the productivity of workers, so this tradeoff could increase or decrease the quality of the civil service.

Those who have studied the impact of veterans' preference have typically looked at pay differences between veterans and equally educated and experienced nonveterans of the same race and sex, expecting that preference leads veterans to earn more than comparable nonveterans. There are two problems with this approach for assessing the impact of veterans' preference on the quality of the civil service. First, the consistent finding is that veterans earn less than comparable nonveterans, implying that the federal service discriminates against veterans or that veterans are less qualified than equally experienced and educated nonveterans. Second, we want to compare the productivity of veterans not to nonveterans with the same characteristics but to the nonveterans who would have been hired in the absence of veterans' preference.

I restrict the sample to full-time employees in the General Schedule (GS) and equivalent pay schedules. GS positions are classified into 15 grades, based on the difficulty and responsibility of the work involved. I track the mean grade of employees who were hired into the five most common entry grades for ten years. If veteran and nonveteran new hires in the same grade are equally qualified, they should progress at approximately the same rate, on average.

\section{Findings}


Impact on probability of holding a government job. Veterans are far more likely than nonveterans to have federal jobs but only a bit more likely than nonveterans to have state and local government jobs (Table 1). In the 2006-9 ACS, for instance, $10.5 \%$ of veterans and only $2.9 \%$ of nonveterans worked for the federal government, and $14.6 \%$ of veterans and $14.2 \%$ of nonveterans worked for state and local governments. That is, veterans were 3.6 times as nonveterans to be federal employees. The percentages vary somewhat across the years, but veterans are always 3-to-4 times as likely as nonveterans to hold federal jobs and never more than $10 \%$ more likely than nonveterans to hold state and local government jobs.

-- -- -- Table 1 about here -- -- --

Potentially, veteran-nonveteran differences in gender, race, age, education, and sexual orientation could account for those differences in sector of employment. The multinomial logit models, however, control for all those variables and still find that veterans are far more likely than comparable nonveterans to hold federal jobs. The second panel of Table 1 shows that veterans' odds of federal rather than private sector employment are 3.5 to 4.2 times as high as the odds for comparable nonveterans. Veterans' odds of state and local employment, however, are only $9 \%$ to $22 \%$ higher than those of nonveterans. The third panel uses the multinomial logit findings to predict each person's probabilities of employment in each sector twice, once as a veteran and once as a nonveteran; then calculates the mean probabilities of employment in each sector for veterans and nonveterans, holding all other variables at their actual distribution in the sample. In 2006-9, for instance, the average predicted probability of holding a federal job was $9.7 \%$ if employees were coded as veterans and only $2.8 \%$ if they were coded as nonveterans. In $2006-9$, this controlled difference $(9.7 \%$ versus $2.8 \%)$ is somewhat 
smaller than the uncontrolled difference (10.5\% versus $2.9 \%)$, but the controlled difference is unchanged in 2000 and is somewhat larger in 1990. That is, differences in the individual characteristics of veterans and nonveterans can explain some of the differences in their employment sectors in 2006-9, but not in 1990 or 2000.

Veterans' higher probability of federal employment holds across all sub-groups. Figure 1 shows that the percentage of veterans who held federal jobs in 2006-9 was substantially higher than the percentage of nonveterans of the same sex who did so at each year of birth. Table 2 shows the percentages of veterans and nonveterans who hold federal jobs within several sub-groups, plus the ratio of those percentages. In general, veteran status makes more difference for women and minorities than for white men. Among whites, for instance, $14.8 \%$ of female and only $8.8 \%$ of male veterans held federal jobs, with veterans 5.5 times as likely as nonveterans to have federal jobs among women and only 3.8 times as likely to do so among men. Veterans' preference increases the probability of federal employment more for naturalized than for native-born citizens, for those born since 1970 than for those born earlier, and for less-educated Americans. Although Native Americans and partnered gay men are more likely to hold federal jobs if they are veterans than if they are not, however, the boost appears to be smaller than for white and married men. ${ }^{4}$

-- -- -- Figure 1 and Table 2 about here -- -- --

The fourth panel of Table 1 therefore allows the impact of veterans' preference on sector of employment to vary with individual characteristics, by working from multinomial logit

\footnotetext{
${ }^{4}$ Multinomial logit analyses done separately for each sex for each year of birth and for each sub-group (not shown) confirm that the patterns hold even after controlling for the other variables. The veteran coefficient is always highly significant and generally larger for groups for whom the ratios are larger.
} 
models that includes interaction terms between veteran and all the other independent variables. Holding the other variables constant, veteran status increases the log-odds of federal employment more for women and minority men than for white men, more for married people than for those in other relationship categories, more for naturalized than for native-born citizens, and more for younger than older Americans (results not shown). Allowing for this differential effect of veteran status on federal employment, the unexplained veterannonveteran difference in probability of federal employment is actually wider in each period than the difference without controlling these other variables. In sum, veterans are substantially more likely than comparable nonveterans to be federal employees. The simple differences of percentages are not overstating the difference.

I also ran the multinomial logit models separately for each state in 2006-9. Veterans were significantly more likely than comparable nonveterans to hold federal jobs in every state, but state and local government jobs in only ten states (California, Connecticut, Florida, Illinois, Massachusetts, New Jersey, New York, Pennsylvania, Vermont, and Washington). Preference might be stronger in these states (Massachusetts and New Jersey have absolute veterans' preference (Davis 1985)), or the statistical significance may just be a function of sample size (all except Vermont are in the 15 most populace states ), but the veteran coefficients are split almost equally between positive and negative across the 50 states, and veterans are significantly less likely to hold state and local government jobs in four states (Georgia, Oklahoma, South Carolina, and Virginia). The over-representation of veterans in some state and local governments may indicate that public sector jobs are particularly desirable in those states. 


\section{Veterans' preference and the composition of the federal service. The Census data}

confirm that some groups - especially men - are more likely than others to be veterans (Table 3). In $2006-9$, for instance, $91 \%$ of veterans and only $52 \%$ of nonveterans are men. In addition, higher percentages of veterans than nonveterans are white ( $81 \%$ versus $72 \%)$ and black (10\% versus $9 \%$ ), but smaller percentages are Latino (6\% versus $12 \%)$ and Asian ( $1 \%$ versus $5 \%$ ). Men with male partners are only half as likely as married men to have served in the military $(7.8 \%$ versus $15.6 \%)$, whereas women with female partners are four times as likely as married women to be veterans (5.4\% versus $1.4 \%)$. (The numbers with same-sex partners are too small to show well in Table 2.) Naturalized citizens are only one-third as likely as native-born citizens to have military service (3.1\% versus $9.6 \%$ ). The veteran population has become more diverse over time. The percentage who are men dropped from $97 \%$ in 1990 to $91 \%$ in $2006-9$, and the white male percentage dropped from $84 \%$ to $76 \%$.

\section{-- -- -- Table 3 about here -- -- --}

The final two columns of Table 3 use the federal personnel data for white-collar federal employees. Veterans who are civil servants are more diverse than veterans generally. Over $21 \%$ are women, more than twice the percentage of veterans overall who are female. Still, white men make up nearly twice as big a share of veterans as of nonveterans in the federal service (54\% versus $30 \%$ ), and women of each race/ethnicity compose more than twice as high a percentage of nonveterans as of veterans. Patterns for new hires over the past decade are similar to those for all federal white-collar employees in 2009 , though about $2.5 \%$ more of the veteran new hires than of federally employed veterans generally are women. 
Table 4 reports the percentages of federal employees who belong to various sub-groups and the percentages who would be predicted to belong to those sub-groups if the probabilities of holding federal jobs were predicted by the patterns for nonveterans. In 2006-9, for instance, white women make up $24.9 \%$ of federal employees but are predicted to compose $28.8 \%$ in the absence of veterans' preference. The model predicts that, if veterans' preference had never existed, the federal civil service would have been almost perfectly split between men and women in all three periods, instead of the female percentage of federal employees rising slowly from $39.3 \%$ in 1990 to $43.2 \%$ in $2006-9$. The racial composition, however, would have been nearly unchanged, because gains for white and black women would have been offset by losses for white and black men. (Asian and other/mixed race men would gain from the absence of veterans' preference, as would Hispanic men in the most recent period.) In the absence of veterans' preference, representation would also rise for naturalized and non-citizens and for partnered gay men (but not partnered lesbians), though the latter effects are too small to show up in Table 4.

-- -- -- Table 4 about here -- -- --

Because veterans' preference has much less impact on whether one works for state and local governments than for the federal service, it has little impact on the composition of the state and local workforce. I ran the analysis separately for the 10 states where being a veteran had a significant positive impact on getting a state or local government job and for the other 40 states. Although men composed a higher percentage of the state and local workforce in those 10 states, statistically removing veterans' preference from the system changed the gender composition in each group of states by less than half a percentage point. 
Veterans' preference and the quality of the federal service. On average, veterans and nonveterans are equally educated in the population, but mostly because there is less variation among the veterans: they are more likely to have graduated high school but less likely to have graduated college. In 2006-9, for instance, the mean years of education for both veterans and nonveterans was 13.9 , but $8.6 \%$ of nonveterans and only $2.3 \%$ of veterans had not finished high school (Table 3). In contrast, $34.1 \%$ of nonveterans and only $26.9 \%$ of veterans held bachelor's or graduate degrees.

Federal white-collar employees are more educated than the general workforce - over 99\% are high school graduates and nearly half are college graduates. CPDF data show that veterans are older and less educated than nonveterans, with the patterns stronger for new hires than for the civil service as a whole. Among those hired into white-collar jobs since 1999, $53.5 \%$ of the nonveterans and only $33.3 \%$ of the veterans had completed college, and $20.5 \%$ of nonveterans and only $10.4 \%$ of veterans held graduate degrees. On average, the newly hired nonveterans had one more year of education than the newly hired veterans. However, the veteran new hires were nearly six years older than the nonveterans.

Thus, veterans' preference appears to increase experience levels at the expense of educational levels in the federal service. As both education and experience increase productivity, this tradeoff could increase or decrease the quality of the civil service. ${ }^{5}$

\footnotetext{
${ }^{5}$ Using the 2006-9 ACS on a sample restricted to white males working in the private, for-profit sector (the group among whom pay differences should be most likely to reflect productivity), an additional year of education raises expected salary by $12 \%$; during the early career, an additional three years of experience would have the same impact (though after about 15 years, experience has very little impact). If these pay differences reflect real productivity differences, getting an additional six years of experience in return for giving up one year of education among new hires could be increasing the quality of the federal service.
} 
Nonveteran new hires, however, are advancing more quickly than nonveterans hired into the same entry grades (Figure 2). Within two years, the mean grades of nonveterans are noticeably higher than veterans starting at the four most common entry grades, and pattern persists over the first fifteen years of their federal civilian careers. Among employees who entered in GS5, for instance, mean grades five years later were 7.9 for veterans and 8.4 for nonveterans; after ten years, the means were 9.0 and 9.6, respectively. Most strikingly, veterans who entered in GS7 had a mean grade of only 9.8 after five years, whereas nonveterans' mean was 11.0; after ten years, nonveterans remained 1.2 grades higher (11.7 versus 10.5). Among those who entered in GS9, nonveterans gained 0.9 grade on veterans after five years and maintained a lead of 0.8 grade after ten years. ${ }^{6}$ -- -- -- Figure 2 about here -- -- --

In sum, veterans' preference appears to increase experience levels but decrease educational attainment in the white-collar civil service. Veteran new hires were 6 years older but had one less year of education than nonveterans, on average. Perhaps because veterans begin their federal civilian careers later in life, their careers do not progress as rapidly as nonveterans entering at the same levels. Ten years later, nonveterans are 0.6 to 1.3 grades higher, on average, than veterans who entered at the same levels. If advancement accurately reflects performance, nonveteran new hires tend to have more potential than veterans.

\footnotetext{
${ }^{6}$ Following the previous research, I also ran regression models for veteran-nonveteran
} grade differences (controlling for education, age, experience, race, and sex) for each year and for each level of federal civilian service. Veterans had lower expected grades than nonveterans in every model, typically by about one-half grade. I also ran logit models, controlling for the same variables, plus GS-level, for whether comparable veterans and nonveterans were equally likely to be promoted and to receive outstanding performance ratings. They were, 


\section{CONCLUSION}

Veterans' preference has a powerful impact on who gets hired in the federal service. Americans who have served in the military are three-to-four times as likely to obtain federal jobs as Americans who have not. The strikingly higher probabilities of federal employment hold for men and women, whites and minorities, heterosexuals and gay/lesbians of every age and education level. The basic pattern holds after controlling for all these variables simultaneously.

As one-quarter of federal employees receive veterans' preference, at least $16 \%$ of federal employees would be different people if veterans' preference had never existed. Because men still outnumber women in the U.S. military by 6-to-1, preferential treatment of veterans in hiring has very disproportionately benefited men. If - in the absence of veterans' preference - gender, race/ethnicity, age, education, and sexual orientation affected probabilities of federal employment for everyone the way they currently affect nonveterans, federal jobs might have been split almost equally between men and women since 1990 . The numbers of Hispanics, Asians, and gay men might also be $20 \%$ higher.

Questions about how the quality of the federal service would differ are more difficult to answer. Veterans' preference clearly leads to older, less-educated people being hired. Veteran new hires appear to have lower potential, on average, than nonveterans hired into the same entry grades. The nonveterans move ahead within the first two years and remain in somewhat higher grades over the first fifteen years of the career.

Although veterans' preference programs in the states are similar to (and sometimes stronger than) the federal program, veterans are only slightly more likely than comparable nonveterans to work for state and local governments and only in some states. This provides 
additional evidence that federal jobs are desirable. Even after decades of bureaucrat-bashing and numerous reports that federal workers are underpaid, Americans still want federal jobs and groups that get preferential treatment take advantage of it. Worries that the federal service cannot attract highly qualified applicants seem overstated.

Is veterans' preference worth its obvious costs to the diversity and the less clear costs to the quality of the federal service? The answer is a political one, weighing the relative values of veterans' sacrifices and other goals of the federal personnel system. One decade into the wars in Iraq and Afghanistan, with the Obama administration apparently firmly committed to increasing employment of veterans and with partisan polarization making any policy change that could be considered as disrespecting our troops extremely dangerous politically, we are unlikely to see any changes in veterans' preference in the near future. We should be clear, however, that preference is a powerful tool that does not come without costs. 


\section{REFERENCES}

Berger, Mark C., and Barry T. Hirsch. 1983. "The Civilian Earnings Experience of Vietnam-Era Veterans." The Journal of Human Resources no. 18 (4):455-479.

Berube, Alan. 1990. Coming Out under Fire: The History of Gay Men and Women in World War II. New York: Free Press.

Blank, Rebecca M. 1985. "An Analysis of Workers' Choice between Employment in the Public and Private Sectors." Industrial \& Labor Relations Review no. 38 (2):211-224.

Clemmitt, Marcia. 2009. "Women in the Military: Should Combat Roles Be Fully Opened to Women?" CQ Researcher no. 19 (40):957-980.

Davis, Charles. 1985. "Veterans' Preference Benefits and Competing Personnel Policy Objectivies in the Public Sector: Can They Be Reconciled?" In Public Personnel Policy: The Politics of Civil Service, edited by David H. Rosenbloom, 96-107. Port Washington, NY: Associated Faculty Press.

Elliott, Robert H. 1986. "The Fairness of Veterans' Preference in a State Merit System: The Employees' View." Public Personnel Management no. 15 (3):311-21.

Emmert, Mark A., and Gregory B. Lewis. 1982. "Veterans Preference and the Merit System." In Centenary Issues of the Pendleton Act of 1883, edited by David H. Rosenbloom, 45-61. New York: Marcel Dekker, Inc.

FedsHireVets. 2011. Veterans' Preference 2011 [cited August 11 2011]. Available from http://www.fedshirevets.gov/job/vetpref/index.aspx.

Gates, Gary J. 2004. Gay Men and Lesbians in the US Military: Estimates from Census 2000. Washington, DC: Urban Institute. 
Grandjean, Burke D. 1981. "History and Career in a Bureaucratic Labor Market." American Journal of Sociology no. 86 (5):1057-1092.

Hale, Mary M., and Rita Mae Kelly. 1989. Gender, Bureaucracy, and Democracy: Careers and Equal Opportunity in the Public Sector. Greenwood Press: New York.

Johnson, Ronald N., and Gary D. Libecap. 1989. "Bureaucratic Rules, Supervisor Behavior, and the Effect on Salaries in the Federal Government." Journal of Law, Economics, and Organization no. 5 (1):53-82.

Keeton, Kato B. 1994. "Women's Access to Federal Civil Service Management Positions: The Issue of Veterans' Preference." Southeastern Political Review no. 22 (1):37-49.

Krueger, Alan B. 1988. "The Determinants of Queues for Federal Jobs." Industrial \& Labor Relations Review no. 41 (4):567-581.

Lewis, Gregory B. 1988. "Progress toward Racial and Sexual Equality in the Federal Civil Service?" Public Administration Review no. 48 (3):700-707.

Lewis, Gregory B., and Mark A. Emmert. 1984. "Who Pays for Veterans' Preference?" Administration \& Society no. 16 (3):328-345.

Lewis, Gregory B., Cathy Yang Liu, and Jason Edwards. 2011. The Representation of Immigrants in Federal, State and Local Government Workforce. In Midwest Political Science Association. Chicago.

Lewis, Gregory B., and David W. Pitts. 2011. "Representation of Lesbians and Gay Men in Federal, State, and Local Bureaucracies." Journal of Public Administration Research and Theory no. 21 (1):159-180. 
Losey, Stephen. 2010. Board Shuts Intern-Hiring Loophole. Federal Times,

http://www.federaltimes.com/article/20101114/PERSONNEL01/11140302/1049/PERSO NNEL.

Lutz, Amy. 2008. "Who Joins the Military?: A Look at Race, Class, and Immigration Status." Journal of Political and Military Sociology no. 36 (2):167-188.

Mani, Bonnie G. 1999. "Challenges and Opportunities for Women to Advance in the Federal Civil Service: Veterans' Preference and Promotions." Public Administration Review no. 59 (6):523-534.

Moulton, Brent R. 1990. "A Reexamination of the Federal-Private Wage Differential in the United States." Journal of Labor Economics no. 8 (2):270-293.

Obama, Barack. 2010. Presidential Memorandum -- Improving the Federal Recruitment and Hiring Process.

Perry, James L., and Lois Recascino Wise. 1990. "The Motivational Bases of Public Service." Public Administration Review no. 50 (3):367-373.

President's Pay Agent. 2011. Report on Locality-based Comparability Payments for the General Schedule. Washington, DC: U.S. Department of Labor, Office of Management and Budget, and Office of Personnel Management,.

Rimmerman, Craig A. . 1996. Gay Rights, Military Wrongs: Political Perspectives on Lesbians and Gays in the Military. New York: Garland.

Rosenberg, Alyssa. 2009. Court Rules Veterans' Preference Applies to Excepted Service Jobs. Government Executive, http://www.govexec.com/dailyfed/0109/010709ar1.htm. 
Sanders, Jimy. 2007. "Nativity, Human Capital, and Government Employment." Social Science Research no. 36 (1):404-420.

Shilts, Randy. 1993. Conduct Unbecoming: Gays \& Lesbians in the U.S. Military. New York: St. Martin's Press.

Smith, Sharon P. 1976. "Pay Differences between Federal Government and Private Sector Workers." Industrial and Labor Relations Review no. 29:176-97.

Smith, Sharon P. 1975. "Pay Differentials between Federal Government and Private Sector Workers." Industrial \& Labor Relations Review no. 29 (2):179-197.

Taylor, Patricia A. 1979. "Income Inequality in the Federal Civilian Government." American Sociological Review no. 44 (3):468-479.

Tsugawa, James. 2011. PMF and Pathways Programs. In PMF and Pathways Programs: Reinventing the Old and Implementing the New. Washington, DC.

U.S. General Accounting Office. 1977. Conflicting Congressional Policies: Veterans' Preference and Apportionment vs. Equal Employment Opportunity. Washington, DC.

- - . 1992. Federal Hiring: Does Veterans' Preference Need Updating? Washington, DC.

U.S. Merit Systems Protection Board. 1994. Entering Professional Positions in the Federal Government. Washington, DC.

- - 2008. Federal Appointment Authorities: Cutting through the Confusion. Washington, DC: MSPB.

U.S. Office of Personnel Management. 2011. Employment of Veterans in the Federal Executive Branch: Fiscal Year 2010. Washington, DC. 
Wooldridge, Jeffrey M. 2009. Introductory Econometrics: A Modern Approach. 4 ed. Mason, $\mathrm{OH}$ : South Western Cengage Learning. 
Table 1. Veteran-Nonveteran Differences based on Census Data

\begin{tabular}{|c|c|c|c|}
\hline & $\underline{2006-9}$ & $\underline{2000}$ & $\underline{1990}$ \\
\hline \multicolumn{4}{|l|}{ Percentage with } \\
\hline \multicolumn{4}{|l|}{ Federal Jobs } \\
\hline Eligible for veterans' preference & 11.7 & 9.9 & 9.8 \\
\hline Other military service & 9.2 & 9.0 & 14.0 \\
\hline No military service & 2.7 & 3.0 & 3.8 \\
\hline
\end{tabular}

\section{Logit Model for \\ Federal Employment}

Eligible for veterans' preference

1.479

1.205

(108.55)

(124.71)

0.992

(110.69)

Other military service

$\begin{array}{rrr}1.200 & 1.193 & 1.639 \\ (71.30) & (90.48) & (127.67)\end{array}$

\section{Regression Model for}

Federal Pay

Eligible for veterans' preference

$\begin{array}{lrr}-1.4 \% & -6.6 \% & -1.6 \% \\ (2.81) & (20.39) & (4.95)\end{array}$

Other military service

$\begin{array}{lrr}-0.3 \% & -5.0 \% & -13.2 \% \\ (0.74) & (10.50) & (28.76)\end{array}$

Regression Model for

Private (For-Profit) Pay

Eligible for veterans' preference

$-0.9 \%$

$-0.6 \%$

$+5.1$

(3.76)

(4.66)

(44.56)

Other military service

$-3.4 \%$

$-6.0 \%$

$-8.9 \%$

(12.07)

(34.08)

(45.48)

Observations (millions)

3.2

3.5

3.0

Robust z statistics in parentheses; all coefficients are significant at .001 level except the federal pay differences in 2006-9. 
Table 2. Characteristics of Veteran and Nonveteran in the Federal Service

All Federal Employees (ACS, 2006-9)

$\underline{\text { Nonveteran }}$

Percentages:

Male

White

Black

Latino

Asian

American Indian

Other/mixed race

Native-born citizen

Naturalized citizen

Non-citizen

Married

Opposite-sex partner

Same-sex partner

No partner

Means:

Years of education

Age

All New Hires (CPDF, 1999-2009)

Means:

Years of education (mean)

Age 34.7

Percentages:

No college

Some college

Bachelor's degree

Master's degree

Professional degree

Doctorate

Recent graduate

Male

White male

Black male
49.7

66.2

$15.6 * * *$

$8.4 * * *$

$6.5 * * *$

$1.7 * * *$

1.6

89.7

$7.8^{* * *}$

$2.5^{* * *}$

62.2

$4.0 * * *$

$0.6^{* * *}$

33.3

$14.7^{* * *}$

45.6

$15.0 * * *$

$40.2^{* * *}$

$31.9 \%$

16.8

29.8

12.9

4.3

4.2

$16.9 * * *$

47.7

32.6

5.3
14.5

$52.7^{* * *}$

$42.4 \%$

7.1

$78.6^{* * *}$

$73.2^{* * *}$

14.5

6.9

2.8

1.0

1.6

$95.9 * * *$

4.0

0.1

$75.5^{* * *}$

2.5

0.3

21.6

14.0

25.7

20.2

9.8

0.9

0.9

$55.0 * * *$

$13.1^{* * *}$ 
Hispanic male

Asian male

Native American male

White female

Black female

Hispanic female

Asian female

Native American female
4.9

$3.7^{* *}$

0.9

$31.9 * * *$

$10.4^{* * *}$

$4.3^{* * *}$

$4.0^{* *}$

$1.4^{* * *}$
$6.9 * * *$

2.5

0.6

11.6

7.1

1.7

0.6

0.3

\section{Professionals and Administrative New Hlres Only (CPDF, 1999-2009)}

\section{Mean education, by grade}

GS-5

GS-7

GS-9

GS-11

GS-12

GS-13

Combined
$14.9 * * *$

$15.9 * * *$

$16.2^{* * *}$

$16.7^{* * *}$

$16.5^{* * *}$

$16.9 * * *$

$16.2^{* * *}$

29.9

28.8

32.7

37.8

39.9

42.7

34.3

Combined

Percentage male, by grade

GS-5

GS-7

GS-9

GS-11

GS-12

GS-13

Combined
63.0

47.6

48.5

44.6

54.9

63.6

51.7
13.6

15.2

14.4

14.3

14.8

15.7

14.7

$40.0 * * *$

$38.3^{* * *}$

$40.6^{* * *}$

$42.6^{* * *}$

$43.2^{* * *}$

$44.1^{* * *}$

41.6***

$85.7^{* * *}$

$77.2^{* * *}$

$78.2^{* * *}$

$83.2^{* * *}$

$88.8^{* * *}$

$83.7^{* *}$

$82.3 * * *$ 
Table 3. Logit Model for Federal Employment

Qualifies for veterans' preference

Other military service

Black male

Hispanic male

Asian male

Native American male

Other/mixed male

White female

Black female

Hispanic female

Asian female

Native American female

Other/mixed female

Man with male partner

Woman with female partner

Naturalized citizen
1990

Model 1

.99

110.7

1.64

(127.7)

$\begin{array}{ll}.77 \quad .72 \\ -63.3) & (57.7)\end{array}$

(63.3) (57.7)

$.38 \quad .38$

$\begin{array}{ll}.71 & .84\end{array}$

(29.4) (34.7)

$\begin{array}{cc}\cdot & \cdot \\ .80 & .74 \\ (22.4) & (20.1) \\ -.23 & .24 \\ (26.6) & (25.4) \\ .74 & 1.19 \\ (54.9) & (84.3) \\ .09 & .53 \\ (4.5) & (25.7) \\ .42 & .77 \\ (13.8) & (25.1)\end{array}$

. .

$\begin{array}{cc}.96 & 1.41 \\ (25.1) & (36.4) \\ -.30 & -.15 \\ (3.4) & (1.7) \\ .03 & -.13 \\ (0.3) & (1.3) \\ -.44 & -.29 \\ (22.9) & (15.0)\end{array}$

2000

\begin{tabular}{ccc} 
Model 1 & & Model 2 \\
\cline { 1 - 1 }. & & 1.22 \\
& $(128.1)$ \\
. & 1.23 \\
& $(93.4)$ \\
.84 & .76 \\
$(67.5)$ & $(59.9)$ \\
.46 & .47 \\
$(24.9)$ & $(25.5)$ \\
.75 & .88 \\
$(32.5)$ & $(37.8)$
\end{tabular}

$\begin{array}{cc}.67 & .62 \\ (27.5) & (24.8) \\ -.14 & .29 \\ (15.4) & (29.5) \\ .87 & 1.25 \\ (66.2) & (91.2) \\ .29 & .65 \\ (13.3) & (29.1) \\ .59 & .87 \\ (21.7) & (31.7)\end{array}$

$\begin{array}{ll}.80 & 1.17\end{array}$

(30.9) (44.4)

$\begin{array}{ll}-.13 & .04\end{array}$

$(2.0) \quad(0.6)$

$-.04 \quad-.21$

(0.6) (3.0)

$-.51 \quad-.35$

(28.9) (20.0)
2006-9

\begin{tabular}{cc} 
Model 1 & Model 2 \\
& 1.48 \\
& $(108.6)$ \\
. & 1.20 \\
& $(71.4)$ \\
.66 & .57 \\
$(37.2)$ & $(31.8)$ \\
.30 & .32 \\
$(12.9)$ & $(13.5)$ \\
.64 & .74 \\
$(24.1)$ & $(27.7)$ \\
.95 & .88 \\
$(16.1)$ & $(14.3)$ \\
.50 & .42 \\
$(8.6)$ & $(9.2)$ \\
-.24 & .13 \\
$(20.4)$ & $(10.3)$ \\
.67 & .99 \\
$(37.7)$ & $(54.2)$ \\
.11 & .41 \\
$(4.1)$ & $(15.1)$ \\
.50 & .74 \\
$(16.9)$ & $(24.5)$ \\
1.26 & 1.62 \\
$(23.7)$ & $(30.1)$ \\
.43 & .73 \\
$(8.6)$ & $(14.7)$ \\
-.31 & -.14 \\
$(4.1)$ & $(1.9)$ \\
.00 & -.13 \\
$(0.0)$ & $(1.7)$ \\
-.48 & -.34 \\
$(22.4)$ & $(16.2)$ \\
& \\
\hline
\end{tabular}


Table 4. Veteran-Nonveteran Differences in Salaries, Promotions, and Outstanding Ratings

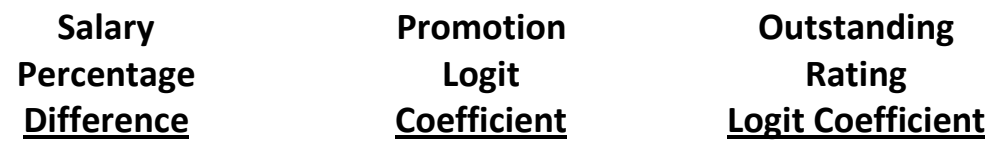

1973

1974

1975

1976

1977

1978

1979

1980

1981

1982

1983

1984

1985

1986

1987

1988

1989

1990

1991

1992

1993

1994

1995

1996

1997

1998

1999

2000

2001

2002

2003

2004

2005

2006

2007

2008

2009
$1.3^{*}$

$1.2^{*}$

$-0.3$

$-2.2^{* *}$

-1.8 *

$-3.1 * *$

$-3.6 * *$

$-3.2 * *$

$-3.5^{* *}$

$-5.1 * *$

$-5.2 * *$

$-4.5^{* *}$

$-4.8 * *$

$-4.4 * *$

$-3.9 * *$

$-4.7 * *$

$-4.3 * *$

$-4.9 * *$

$-5.8 * *$

$-6.0 * *$

$-6.1^{* *}$

$-6.4^{* *}$

$-6.9 * *$

$-6.6 * *$

$-6.4 * *$

$-6.6 * *$

$-7.5 * *$

$-7.2 * *$

$-7.2^{* *}$

$-7.5^{* *}$

$-6.9 * *$

$-6.8 * *$

$-6.6 * *$

$-6.8 * *$

$-6.9 * *$

$-7.8^{* *}$

$-7.4 * *$
0.10

$0.29 * *$

$0.28^{* *}$

0.13

0.06

$0.25^{* *}$

0.20 *

0.08

0.20 *

0.21 *

$-0.05$

0.11

0.01

0.11

0.06

0.02

0.05

0.01

$-0.03$

0.01

0.20 *

0.10

$0.27^{* *}$

0.11

0.23 *

0.19 *

$0.28 * *$

0.20 *

0.08

0.18 *

0.02

0.24 *

0.04

0.10

0.15

$0.33^{* *}$
$-0.01$

0.09

$-0.06$

$-0.06$

$-0.12$

$-0.06$ 
Table 5. Veteran-Nonveteran Differences, by Federal Agency

\begin{tabular}{|c|c|c|}
\hline $\begin{array}{l}\text { Percent of } \\
\text { All Workers }\end{array}$ & $\begin{array}{l}\text { Percent of } \\
\text { New Hires }\end{array}$ & $\begin{array}{l}\text { Percentage } \\
\text { Unexplained }\end{array}$ \\
\hline 2 & 1999-2009 & Pay Gap, 2009 \\
\hline
\end{tabular}

Air Force
Army
Navy
Transportation
Other DOD
Homeland Security
Veterans Affairs
Justice
Interior
Other
Agriculture
Treasury
Social Security
Commerce
Health \& Human Services

36.7

34.1

31.2

29.9

28.0

22.8

21.7

16.7

14.9

12.4

11.9

9.3

8.7

8.2

5.9
48.2

38.8

39.2

34.3

33.3

20.8

20.2

17.3

12.7

12.8

13.0

14.5

8.0

3.8

7.0
$-7.0$

$-10.0$

$-5.5$

$-4.9$

$-2.6$

$-4.4$

$-14.2$

$-13.4$

$-6.6$

$-7.6$

$-6.5$

$-11.7$

$-10.2$

$-11.4$

$-10.1$ 


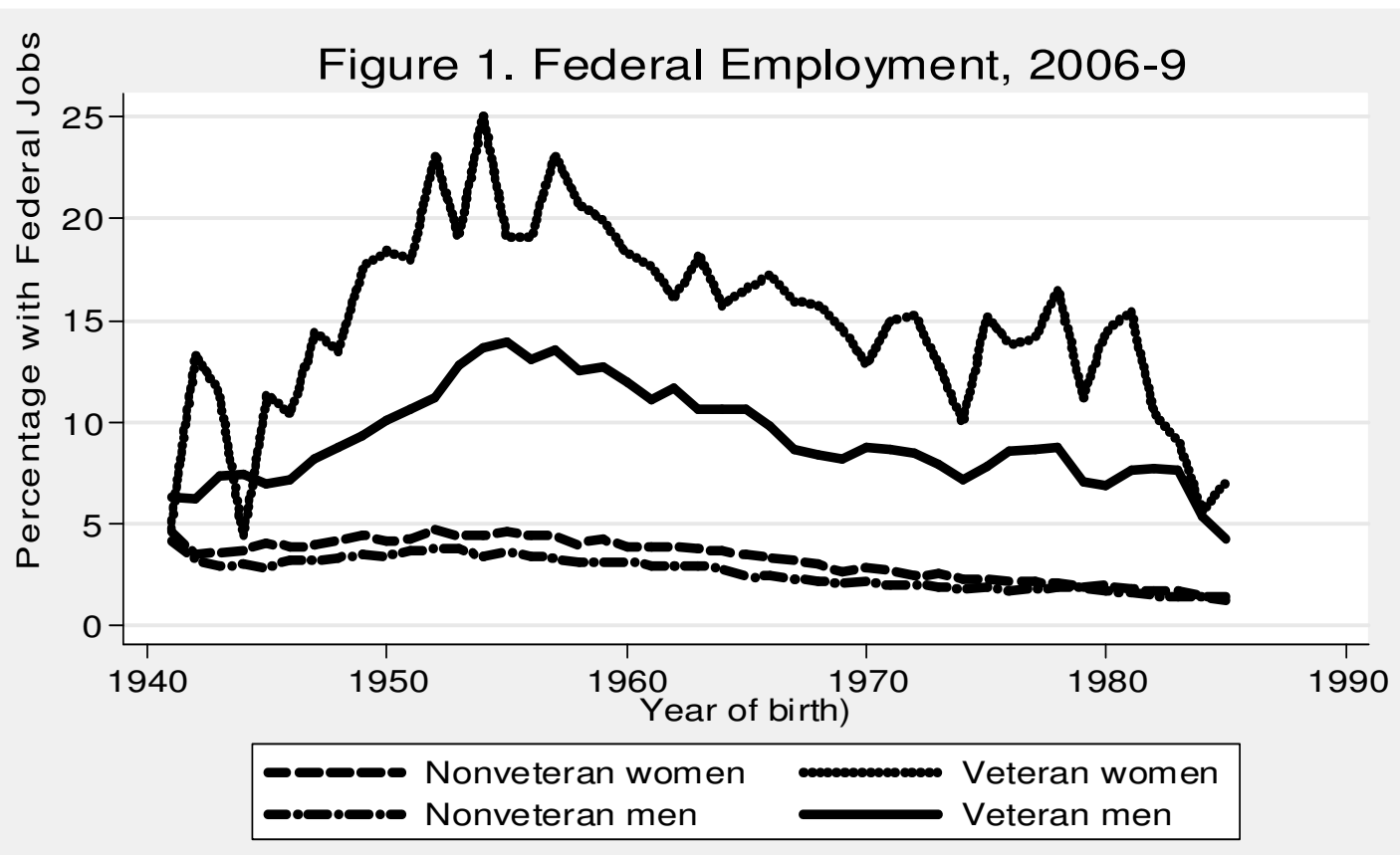

Figure 2. Career Progression by Entry Grade

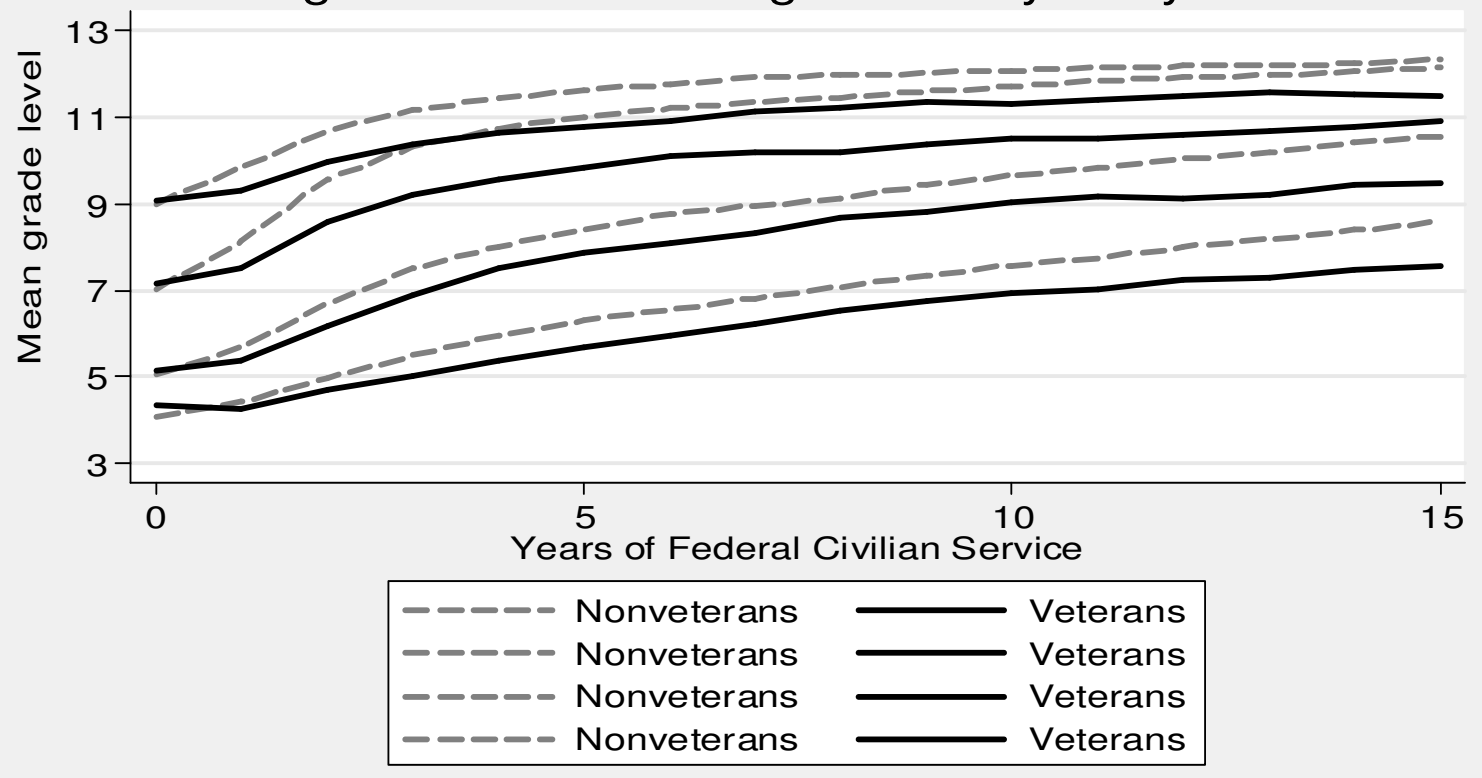

